http://dx.doi.org/10.22319/rmcp.v10i1.4727

Technical note

\title{
Evaluation of clinical, radiological, ultrasonographic and microbiological findings of septic arthritis in $\mathbf{5 0}$ calves
}

İbrahim Yurdakul*

Department of Surgery, Faculty of Veterinary Medicine, Cumhuriyet University, Sivas, TURKEY.

* Correspondence author: ibrahimyurdakul5858@ hotmail.com

\begin{abstract}
:
In this study, it was aimed to evaluate clinical, radiological, ultrasonographic and microbiological findings of calves with septic arthritis. Study material consisted of 50 calves with arthritis in different stocks and gender and aged between 4 to $150 \mathrm{~d}$, brought to the clinic between 2016 and 2017 with lameness complaint. After obtaining medical histories, physical and microbiological examinations of calves' clinical, radiographic, ultrasonographic, synovial samples were conducted. Clinically, monoarthritis was detected in 37 calves and polyarthritis was detected in 13 calves. Most of the lesions were observed in carpal and tarsal joints. In radiography results, increased opacity was found in joints with arthritis, intraarticular narrowing and degeneration on joint surface. In ultrasonographic examinations, the hyperechogenic heterogeneous appearance of synovial fluid and a smooth and apparent hyperechoic joint capsule in articular cartilage surface were observed in 43 cases. Most commonly, Staphylococcus aureus was detected in 13 cases, Trueperella pyogenes was detected in 8 cases, Streptococcus pluranimalium was detected in 8 cases, Mycoplasma bovis was detected in 5 cases, Escherichia coli was detected in 5 cases, Saprophyte spp. was detected in 1 case and Acinetobacter spp. was detected in 1 case in microbiological examination of synovial fluid. In conclusion, the together evaluation of clinical, radiological, ultrasonographic and microbiological findings in the diagnosis of septic arthritis, which is frequently encountered in calves and which causes serious economic losses with high mortality rates, would be a more effective approach for clinical practitioners in terms of treatment and prognosis.
\end{abstract}

Key words: Arthritis, Calf, Clinic, Microbiology, Radiology, Ultrasonography. 
Received: 19/12/2017

Accepted: 18/06/2018

It is indicated that foot diseases encountered in cattle breeding cause serious economic losses such as decrease in milk yield, weight loss, decrease in reproductive performance, treatment expenses and early separation of cattle from the herd because of the disease ${ }^{(1-5)}$. The most common cause of lameness in cattle is nail problems. It is reported that the diseases causing lameness in second rank are arthritides ${ }^{(4,6)}$. Diseases occurring in the joints and ligaments constitute $47 \%$ to $72.2 \%$ of lameness cases caused by extremity ${ }^{(6)}$.

Arthritis are inflammations of components of a joint that shows fever, pain, swelling and lameness symptoms at different levels ${ }^{(7,8)}$. During arthritis, synovial fluid, that is generally clear or slightly pale yellow and viscous, has an egg white appearance, and includes proteins, becomes abnormal, and this fluid contains a large number of leukocytes and microbial pathogens ${ }^{(7,9)}$. Arthritis can affect one, several or all of the components of the joint. Arthritis can occur in only one joint (monoartritis), in multiple joints (polyarthritis), in joint ligaments and their peripheral area (periarthritis), and also in all joint components (panarthritis) ${ }^{(2,10,11)}$. It is classified as acute or chronic according to the clinical course, and aseptic or septic according to the characteristic of the inflammation $^{(2,9,12)}$. In aseptic and septic arthritis, various levels of deformation occur in the components forming the joint, causing functional disorders. Lameness, difficulty in standing, tension in the joint capsule due to synovial fluid increase, swelling, pain and local temperature increase are the most common clinical manifestations ${ }^{(12-14)}$.

Aseptic joint inflammations are usually seen as a result of distortions and overextensions of the joint area of relevant leg during pulling applied in delivery to the calves. On the other hand, septic joint inflammations are caused by the direct occurrence of infection factors on joint regions as a result of trauma or by the replacement via hematogenesis as a result of diseases such as septicemia, omphalitis and pneumonia ${ }^{(8,11,14-17)}$. Especially in young animals, joint infections can occur after bacteremia or sepsis. In addition, calves with hypogammaglobulinemia has been found to be more sensitive to bacteremia and septic $\operatorname{arthritis}^{(7)}$.

Septic arthritis is a very common disease that frequently affects newborn calves ${ }^{(18)}$. The disease generally requires long-term treatment and high medical expenses. For this reason, application of treatment is sometimes not economical due to the high expense ${ }^{(7,18)}$. In addition, the use of inappropriate antibiotics, delayed initiation of treatment, formation of irreversible lesions in tissues and joint structures are reported to be the causes of failure in treatment ${ }^{(7,8,11)}$. Therefore, early diagnosis and treatment of the disease is very important for the reduction of prevalence and economic expenses of the disease ${ }^{(1,14)}$.

Several pathogens have been reported as causes of arthritis in calves in different regions of the world. Several Mycoplasma spp. species such as M. bovis, M. canadense, M. alkalenscens and $M$. 
bovigenitalium have a constructive role in the formation of arthritis in cattle. It is reported that M. bovis is the most common isolated species in arthritis cases encountered in cattle $\mathrm{e}^{(7,13,15,19)}$. However, other pathogens such as Trueperella pyogenes, Actinomyces pyogenes, E. coli, S. aureus, Streptococcus spp. and Salmonella spp. also take an important place in the formation of the disease $^{(13,18,19)}$.

In this study, it was aimed to evaluate the clinical, radiological, ultrasonographic and microbiological findings of the arthritis cases that cause great economic loss and serious health problems in calves.

The material of the study consisted of 50 calves of different breed and gender (33 male and 17 female), aged between 4 to 150 d, brought to Cumhuriyet University Faculty of Veterinary Medicine Surgery Clinic, Sivas Turkey, between 2016 and 2017 with lameness and swelling complaint in joints. The place where the work was conducted; with a continental climate (hot and dry in summers, cold and snowy in winters), with an altitude of $1,285 \mathrm{~m}$ asl.

Medical histories of calves with arthritis were obtained from their owners. Radiological and ultrasonographic examinations of the relevant joint or joints were performed after clinical examinations of the cases. Finally, synovial fluid was taken from joint or joints via aseptic method for microbiological examinations of calves with arthritis.

For general clinical examination, examinations of body temperature, respiration rate, heart rate, mucosal membrane color, capillary filling time and local lymph nodules of calves with arthritis were performed primarily. The umbilical region was examined in terms of possible omphalitis. Following the determination of lameness by the inspection of calves with arthritis during standing and walking the gait and lumbar spine were determined, the relevant joint area was examined for the local temperature increase, swelling and flexion sensitivity.

Radiographs of relevant joint were obtained in mediolateral (ML) and anteroposterior (AP) positions for radiographic examination. For ultrasonographic examination, the calves were put on the operation table, adjusting the position as the relevant joint was on top. Following the shaving of relevant joint hair, the joint was examined longitudinally and transversally. For sedation, xylazine hydrochloride at a dose of $0.05 \mathrm{mg} / \mathrm{kg}$ were given to the calves. Subsequently, antisepsis was ensured on the joint region that arthrocentesis will be applied with baticcon solution. Specific entry direction on the joint was determined, cannula size 18 was inserted into the joint, and approximately $4 \mathrm{ml}$ synovial fluid was aspirated. Approximately $2 \mathrm{ml}$ of aspirated synovial fluid was taken into a sterile tube for physical examination (color, volume, viscosity and fibrin) and the remaining $2 \mathrm{ml}$ were taken into a different sterile tube for microbiological examination. The synovial fluid of the animals with arthritis was sent to a private microbiology laboratory for analysis of the agent, as there was no possibility of microbiological analysis in the animal hospital.

Following the asepsis of the relevant joint of the animal, internal joint area was washed with 500 $\mathrm{mL} 0.9 \%$ physiological saline solution using "true and true" technique for treatment since different 
antibiotics have been given to calves with arthritis by veterinarians or animal owners givers, according to the statements of animal owners. This process was repeated until the aspirated fluid became clear. After irrigation, wet antiseptic compress was applied on the relevant joint with $0.1 \%$ batticon solution, application of wet compress once in every $24 \mathrm{~h}$ for $15 \mathrm{~d}$ was suggested to animal owner. Parenteral antibiotic Ceftiofur sodium (Ecoseft-IE) was given as $1 \mathrm{ml}$ i.m. per $50 \mathrm{~kg}$ live weight for $5 \mathrm{~d}$ until the identification of bacterium in synovial fluid.

Appropriate antibiotic was selected according to the microorganism isolated in microbiological examination of synovial fluid obtained from the joint and antibiotic was given parenterally for 10 d. In addition, flunixin meglumin (Flumeglin-Teknovet) was given for $3 \mathrm{~d}$ for postoperative pain control as $2.2 \mathrm{ml}$ i.m. per $50 \mathrm{~kg}$ live weight. Continuous communication with animal owners was ensured during the treatment period in terms of recovery.

Twenty four (24) of the 50 of calves with arthritis were Montofon calves, 23 were Simmental calves, 2 were indigenous calves and 1 was Holstein calf. Of the Montofon calves, 6 were male and 8 were female, 15 of the Simmental calves were male and 8 were female, all indigenous calves were male and Holstein calf was female. In total, there were 33 male and 17 female calves with arthritis.

Clinically, general findings such as high fever, fatigue, loss of appetite, reduction in mobilization, lameness, pain in the flexion of the relevant joint, local temperature increase, swelling and sensitivity at varying levels were identified in all calves. Beside this, omphalitis was detected in 22 cases. In addition, pneumonia was detected in 2 cases, bloody diarrhea in 1 case and both pneumonia and diarrhea in 2 cases. Thirty-seven (37) calves were diagnosed with monoarthritis, and 13 calves with polyarthritis. Fourty two (42) of the lesions were found in carpal joints, 12 were in tarsal, 3 were in genu, 3 were in metacarpo-phalangeal, 2 were in coxae and 1 was in the cubital joint. The localization and clinical symptoms of the lesion with arthritis are given in Table 1. 
Table 1: Localization and clinical symptoms of lesions in calves with arthritis

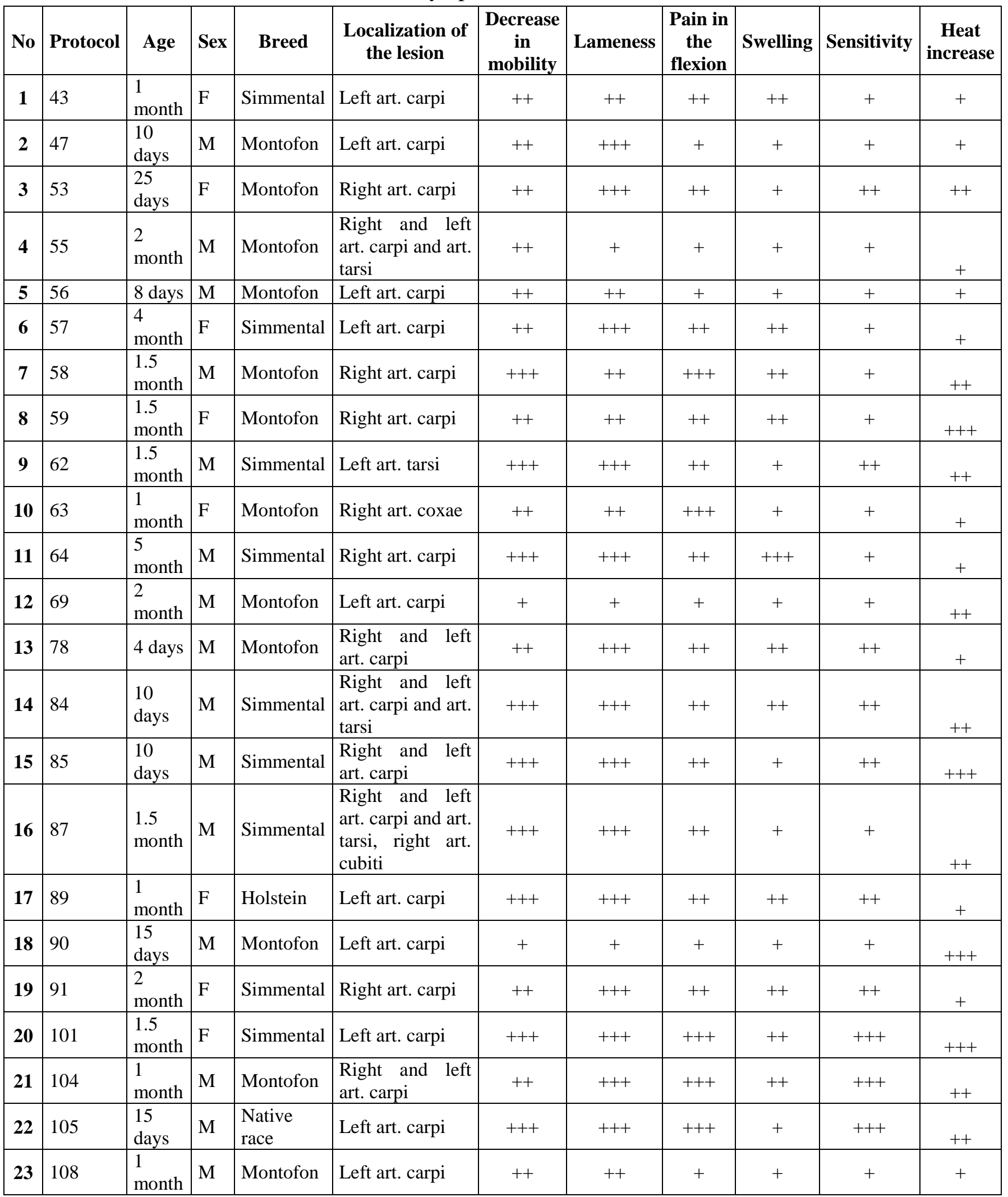




\begin{tabular}{|c|c|c|c|c|c|c|c|c|c|c|c|}
\hline 24 & 109 & \begin{tabular}{l|}
1.5 \\
month
\end{tabular} & $\mathrm{F}$ & Montofon & Left art. carpi & + & + & + & + & + & + \\
\hline 25 & 110 & $\begin{array}{l}1 \\
\text { month }\end{array}$ & $\mathrm{F}$ & Montofon & Right art. carpi & ++ & +++ & ++ & + & ++ & ++ \\
\hline 26 & 113 & $\begin{array}{l}1 \\
\text { month }\end{array}$ & M & Simmental & Right art. genu & + & ++ & + & + & + & + \\
\hline 27 & 117 & $\begin{array}{l}12 \\
\text { days }\end{array}$ & M & Montofon & Left art. carpi & + & + & ++ & + & ++ & ++ \\
\hline 28 & 119 & $\begin{array}{l}2 \\
\text { month }\end{array}$ & $\mathrm{F}$ & Simmental & Left art. carpi & ++ & +++ & ++ & ++ & ++ & + \\
\hline 29 & 128 & $\begin{array}{l}1.5 \\
\text { month }\end{array}$ & $\mathrm{F}$ & Montofon & Left art. tarsi & +++ & +++ & +++ & ++ & +++ & +++ \\
\hline 30 & 129 & $\begin{array}{l}15 \\
\text { days }\end{array}$ & M & Simmental & Left art. tarsi & +++ & +++ & ++ & ++ & ++ & +++ \\
\hline 31 & 130 & $\begin{array}{l}20 \\
\text { days }\end{array}$ & M & Simmental & Right art. carpi & + & +++ & ++ & + & + & + \\
\hline 32 & 132 & $\begin{array}{l}2 \\
\text { month }\end{array}$ & M & Simmental & Right art. genu & ++ & +++ & + & ++ & + & + \\
\hline 33 & 135 & $\begin{array}{l}2 \\
\text { month }\end{array}$ & $\mathrm{F}$ & $\begin{array}{l}\text { Native } \\
\text { race }\end{array}$ & Right art. carpi & ++ & +++ & +++ & + & +++ & +++ \\
\hline 34 & 136 & $\begin{array}{l}1.5 \\
\text { month }\end{array}$ & $\mathrm{F}$ & Montofon & Left art. carpi & +++ & +++ & ++ & + & ++ & + \\
\hline 35 & 138 & $\begin{array}{l}1 \\
\text { month }\end{array}$ & M & Simmental & Right art. carpi & +++ & +++ & +++ & + & +++ & +++ \\
\hline 36 & 140 & $\begin{array}{l}2 \\
\text { month }\end{array}$ & M & Montofon & $\begin{array}{l}\text { Right and left } \\
\text { art. tarsi }\end{array}$ & + & + & + & + & + & + \\
\hline 37 & 141 & $\begin{array}{l}2 \\
\text { month }\end{array}$ & M & Simmental & Right art. carpi & ++ & +++ & + & ++ & ++ & ++ \\
\hline 38 & 144 & $\begin{array}{l}3 \\
\text { month }\end{array}$ & M & Montofon & Left art. carpi & ++ & +++ & +++ & + & +++ & + \\
\hline 39 & 145 & $\begin{array}{l}25 \\
\text { days }\end{array}$ & M & Montofon & Left art. carpi & + & ++ & + & + & + & ++ \\
\hline 40 & 146 & $\begin{array}{l}1.5 \\
\text { month }\end{array}$ & $\mathrm{M}$ & Simmental & $\begin{array}{l}\text { Right art. carpi } \\
\text { and left art. tarsi }\end{array}$ & + & + & + & + & + & + \\
\hline 41 & 149 & \begin{tabular}{l|}
2 \\
month
\end{tabular} & $\mathrm{M}$ & Montofon & Left art. carpi & ++ & +++ & ++ & + & +++ & +++ \\
\hline 42 & 153 & $\begin{array}{l}20 \\
\text { days }\end{array}$ & M & Montofon & Left art. carpi & + & + & + & + & + & + \\
\hline 43 & 155 & $\begin{array}{l}1 \\
\text { month }\end{array}$ & $M$ & Montofon & $\begin{array}{l}\text { Right art. } \\
\text { metacarpo- } \\
\text { phalangealis, } \\
\text { right art. carpi, } \\
\text { right art. tarsi }\end{array}$ & ++ & +++ & + & + & + & ++ \\
\hline 44 & 159 & $\begin{array}{l}15 \\
\text { days }\end{array}$ & M & Simmental & $\begin{array}{l}\text { Right and left } \\
\text { art. carpi and art. } \\
\text { tarsi }\end{array}$ & ++ & +++ & +++ & + & +++ & +++ \\
\hline 45 & 166 & $\begin{array}{l}15 \\
\text { days }\end{array}$ & M & Simmental & \begin{tabular}{|l|} 
Right art. \\
metacarpo- \\
phalangealis
\end{tabular} & + & + & + & + & ++ & ++ \\
\hline 46 & 169 & $\begin{array}{l}1.5 \\
\text { month }\end{array}$ & $\mathrm{F}$ & Montofon & Right art. carpi & +++ & +++ & ++ & ++ & ++ & + \\
\hline 47 & 181 & $\begin{array}{l}2 \\
\text { month }\end{array}$ & $M$ & Simmental & $\begin{array}{l}\text { Right art. carpi, } \\
\text { left art. genu, left } \\
\text { art. coxae }\end{array}$ & ++ & ++ & ++ & + & + & + \\
\hline
\end{tabular}




\begin{tabular}{|c|c|c|c|c|c|c|c|c|c|c|c|}
\hline 48 & 182 & $\begin{array}{l}1 \\
\text { month }\end{array}$ & M & Simmental & $\mid \begin{array}{ll}\text { Right and left } \\
\text { art. carpi, art. } \\
\text { tarsi and art. } \\
\text { metacarpo- } \\
\text { phalangealis }\end{array}$ & +++ & +++ & ++ & + & +++ & ++ \\
\hline 49 & 190 & $\begin{array}{l}2 \\
\text { month }\end{array}$ & $\mathrm{F}$ & Simmental & $\begin{array}{l}\text { Right and left } \\
\text { art. carpi, right } \\
\text { art. tarsi }\end{array}$ & +++ & ++ & ++ & ++ & ++ & ++ \\
\hline 50 & 191 & $\begin{array}{l}2 \\
\text { month }\end{array}$ & $\mathrm{F}$ & Simmental & Right art. carpi & ++ & ++ & + & + & + & + \\
\hline
\end{tabular}

In radiological examination, opacity increase and joint tension due to increased purulence or increased purulence with gas were detected in 18 cases (Figure 1, A,B), intraarticular narrowing and degeneration on joint surface were detected in 6 cases. No abnormality was detected in bone tissue in 26 cases.

Figure 1: a) Radiopacity increase in punctate radiolucent appearance around the tibiotarsal joint due to arthritis purulenta in a case with tarsitis; b) Formed radiolucent appearance due to possible microorganism activity in femoropatellar and femorotibial joints in a case with gonitis

a

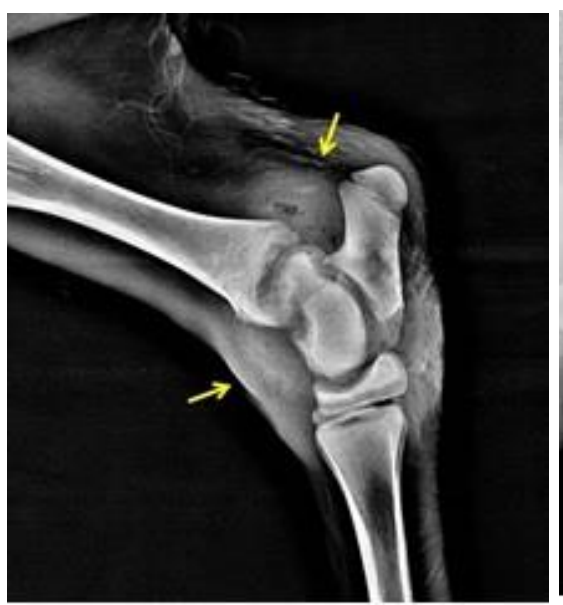

b

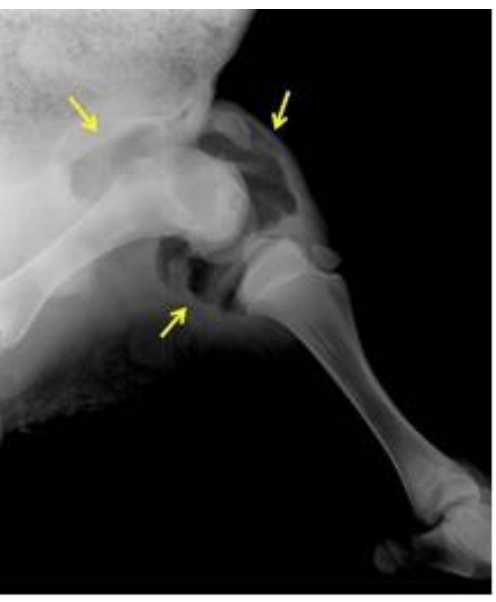

In ultrasonographic examination, enlarged joint space and corpuscular reflective bodies (fibrin deposits or tissue residues) showing intense hyperechogenicity in the anechoic appearance of the synovial fluid were detected in 18 cases; synovial fluid had a hyperechogenic appearance and was heterogeneous (Figure 2a). In 6 cases, the articular cartilage surface had a smooth surface with an acutely apparent hyperechoic line (Figure 2b). No abnormality was detected in 26 cases. 
Figure 2: a) Hyperechogenic and heterogenic appearance of the synovial space in a case with arthritis, (10 d male calf); b) Complex echogenicity and heterogenic appearance of the synovial space and corpuscular spots in the synovial fluid of a case with purulent arthritis, ( $36 \mathrm{~d}$ male calf)

a

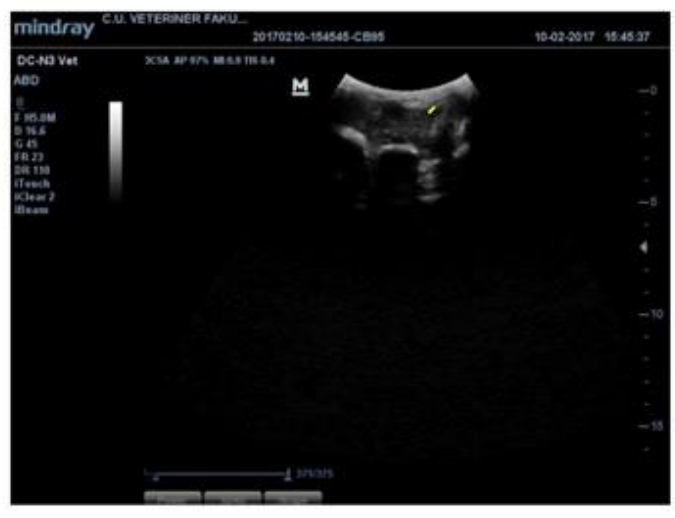

b

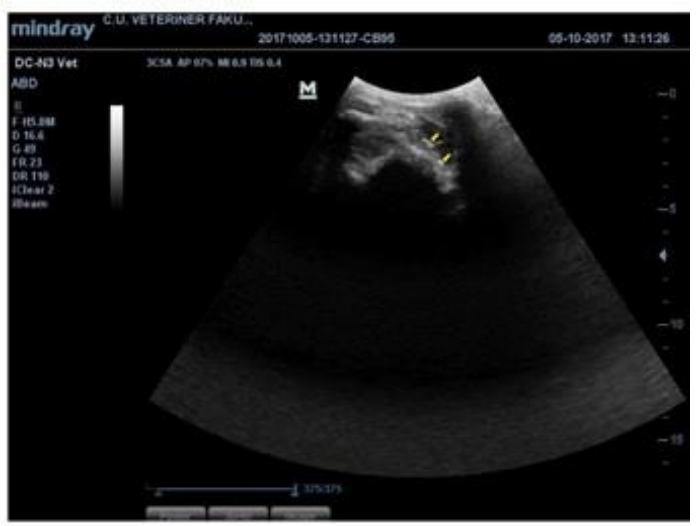

Seven synovial fluids taken from the calves with arthritis were mobile, clear and normal in appearance, 25 synovial fluids were cloudy and in varying colors from light yellow to dark yellowbrown and the synovial fluid viscosity decreased at varying levels, and the synovial fluid was completely purulent in 18 cases. Bacteriologically positive result was obtained from 38 of the synovial fluids, while a negative result was obtained from 12 of them.

According to the results of microbiological analyzes, S. aureus was detected in 13 cases, Trueperella pyogenes in 8 cases, $S$. pluranimalium in 8 cases, Mycoplasma bovis in 6 cases, E. coli in 5 cases Saprophyte spp. in 1 case and Acinetobacter spp. in 1 case (Table 2).

Arthritis is a common disease frequently seen in newborn calves, causing great economic losses, and showing fever, pain, swelling and lameness symptoms at different levels ${ }^{(7,8,18)}$. Clinically, arthritides are classified as aseptic or septic and septic arthritides are important ${ }^{(9,12)}$.

In the presented study, the detection of omphalitis in 22 cases, pneumonia in 2 cases, bloody diarrhea in 1 case and pneumonia and diarrhea in 2 cases suggests that the colostrum given to calves after delivery was not sufficient and thus the infection has spread rapidly, causing septic arthritis and other clinical forms ${ }^{(9,17,20)}$. 
Table 2: Microbiological findings of synovial fluid in calves with arthritis

\begin{tabular}{|c|c|c|c|c|c|c|}
\hline No & Protocol & Age & Sex & Breed & Localization of the lesion & $\begin{array}{c}\text { İsolated } \\
\text { microorganism }\end{array}$ \\
\hline 1 & 43 & 1 month & $\mathrm{F}$ & Simmental & Left art. Carpi & $\begin{array}{l}\text { Streptococcus } \\
\text { pluranimalium }\end{array}$ \\
\hline 2 & 47 & 10 days & M & Montofon & Left art. Carpi & E.coli \\
\hline 3 & 53 & 25 days & $\mathrm{F}$ & Montofon & Right art. Carpi & Mycoplasma bovis \\
\hline 6 & 57 & 4 month & $\mathrm{F}$ & Simmental & Left art. Carpi & Staphylococcus aureus \\
\hline 7 & 58 & $\begin{array}{l}1.5 \\
\text { month }\end{array}$ & M & Montofon & Right art. Carpi & Mycoplasma bovis \\
\hline 8 & 59 & $\begin{array}{l}1.5 \\
\text { month }\end{array}$ & $\mathrm{F}$ & Montofon & Right art. Carpi & $\begin{array}{l}\text { Mycoplasma bovis, } \\
\text { Staphylococcus aureus }\end{array}$ \\
\hline 9 & 62 & $\begin{array}{l}1.5 \\
\text { month }\end{array}$ & M & Simmental & Left art. Tarsi & E.coli \\
\hline 14 & 84 & 10 days & M & Simmental & Right and left art. Carpi and art. Tarsi & $\begin{array}{l}\text { Streptococcus } \\
\text { pluranimalium }\end{array}$ \\
\hline 16 & 87 & $\begin{array}{l}1.5 \\
\text { month }\end{array}$ & M & Simmental & $\begin{array}{l}\text { Right and left art. Carpi and art. Tarsi, right art. } \\
\text { Cubiti }\end{array}$ & Trueperella pyogenes \\
\hline 17 & 89 & 1 month & $\mathrm{F}$ & Holstein & Left art. Carpi & Trueperella pyogenes \\
\hline 18 & 90 & 15 days & M & Montofon & Left art. Carpi & Trueperella pyogenes \\
\hline 19 & 91 & 2 month & $\mathrm{F}$ & Simmental & Right art. Carpi & Trueperella pyogenes \\
\hline 20 & 101 & $\begin{array}{l}1.5 \\
\text { month }\end{array}$ & $F$ & Simmental & Left art. Carpi & Trueperella pyogenes \\
\hline 21 & 104 & 1 month & M & Montofon & Right and left art. Carpi & $\begin{array}{l}\text { Acinetobacter towner, } \\
\text { Staphylococcus aureus. }\end{array}$ \\
\hline 22 & 105 & 15 days & M & $\begin{array}{l}\text { Native } \\
\text { race }\end{array}$ & Left art. Carpi & Trueperella pyogenes \\
\hline 23 & 108 & 1 month & $\mathrm{M}$ & Montofon & Left art. Carpi & Staphylococcus aureus \\
\hline 25 & 110 & 1 month & $\mathrm{F}$ & Montofon & Right art. Carpi & Staphylococcus aureus \\
\hline 28 & 119 & 2 month & $\mathrm{F}$ & Simmental & Left art. Carpi & $\begin{array}{c}\text { Streptococcus } \\
\text { pluranimalium }\end{array}$ \\
\hline 29 & 128 & $\begin{array}{l}1.5 \\
\text { month }\end{array}$ & $F$ & Montofon & Left art. Tarsi & Staphylococcus aureus \\
\hline 30 & 129 & 15 days & M & Simmental & Left art. Tarsi & $\begin{array}{c}\text { Trueperella pyogenes, } \\
\text { Staphylococcus aureus, } \\
\text { E coli }\end{array}$ \\
\hline 31 & 130 & 20 days & $\mathrm{M}$ & Simmental & Right art. Carpi & Mycoplasma bovis \\
\hline 32 & 132 & 2 month & M & Simmental & Right art. Genu & $\begin{array}{l}\text { Streptococcus } \\
\text { pluranimalium }\end{array}$ \\
\hline 33 & 135 & 2 month & $\mathrm{F}$ & $\begin{array}{l}\text { Native } \\
\text { race }\end{array}$ & Right art. Carpi & Trueperella pyogenes \\
\hline 34 & 136 & $\begin{array}{l}1.5 \\
\text { month }\end{array}$ & $\mathrm{F}$ & Montofon & Left art. Carpi & Staphylococcus aureus \\
\hline 35 & 138 & 1 month & $\mathrm{M}$ & Simmental & Right art. Carpi & Staphylococcus aureus \\
\hline 36 & 140 & 2 month & M & Montofon & Right and left art. Tarsi & $\begin{array}{c}\text { Streptococcus } \\
\text { pluranimalium }\end{array}$ \\
\hline 37 & 141 & $\begin{array}{l}2 \\
\text { month }\end{array}$ & M & Simmental & Right art. Carpi & $\begin{array}{l}\text { Streptococcus } \\
\text { pluranimalium }\end{array}$ \\
\hline 38 & 144 & 3 month & $\mathrm{M}$ & Montofon & Left art. Carpi & Staphylococcus aureus \\
\hline 39 & 145 & 25 days & M & Montofon & Left art. Carpi & $\begin{array}{l}\text { Sstreptococcus } \\
\text { pluranimalium }\end{array}$ \\
\hline 40 & 146 & $\begin{array}{l}1.5 \\
\text { month }\end{array}$ & M & Simmental & Right art. Carpi and left art. Tarsi & E.coli \\
\hline 42 & 153 & 20 days & $\mathrm{M}$ & Montofon & Left art. Carpi & E.coli \\
\hline
\end{tabular}




\begin{tabular}{|l|l|l|l|l|l|c|}
$\mathbf{4 4}$ & 159 & 15 days & M & Simmental & Right and left art. carpi, right and left art. tarsi & Staphylococcus aureus \\
\hline $\mathbf{4 5}$ & 166 & 15 days & M & Simmental & Right art. metacarpo- phalangealis & Staphylococcus aureus \\
\hline $\mathbf{4 6}$ & 169 & $\begin{array}{l}1.5 \\
\text { month }\end{array}$ & F & Montofon & Right art. Carpi & Trueperella pyogenes \\
\hline $\mathbf{4 7}$ & 181 & 2 month & M & Simmental & Right art. Carpi, left art. Genu, left art. Coxae & Mycoplasma bovis \\
\hline $\mathbf{4 8}$ & 182 & 1 month & M & Simmental & $\begin{array}{l}\text { Right and left art. Carpi, art. Tarsi and art. } \\
\text { Metacarpo- phalangealis }\end{array}$ & $\begin{array}{c}\text { Mycoplasma bovis, } \\
\text { Streptococcus } \\
\text { pluranimalium }\end{array}$ \\
\hline $\mathbf{4 9}$ & 190 & 2 month & F & Simmental & Right and left art. Carpi, right art. Tarsi & Staphylococcus aureus \\
\hline $\mathbf{5 0}$ & 191 & 2 month & F & Simmental & Right art. Carpi & Saprophyte spp. \\
\hline
\end{tabular}

Early definitive diagnosis of arthritis is possible with clinical, radiological and ultrasonographic examinations as well as with physical and microbiological examinations of synovial fluid ${ }^{(10,21,22)}$. In this study, early diagnosis of joint diseases was ensured with anamnesis and clinical, radiological, and ultrasonographic examinations and was supported by physical and microbiological examinations of the synovial fluid. Clinical findings such as lameness at varying levels, palpation-sensitive, painful, edematous swelling with high fever and restriction of flexion movement have been reported to be observed in calves with arthritis ${ }^{(6,8,11)}$. There was severe lameness observed in 30 cases, moderate lameness in 11 cases and mild lameness in 9 cases. In addition, monoarthritis were detected in 37 calves and polyarthritis in 13 calves in the study. Arthritis cases are reported to be frequently seen in carpal and genu joints in young animals and in tarsal and pastern joints in adult animals ${ }^{(6,17)}$. In this study, the fact that arthritis was detected in carpal joint in 42 of the 50 calves with arthritis and in tarsal joint in 12 calves confirms this information.

The first radiographic findings in arthritis are soft tissue swelling and enlargement of the joint space $24 \mathrm{~h}$ after the formation of the disease due to gas accumulation ${ }^{(11,16,21)}$. Following the progress of the disease, the main radiographic findings are reported to appear about 10 to $14 \mathrm{~d}$ later. In chronic cases, there is a decrease observed in joint space due to subchondral bone lysis, periostitis, osteomyelitis and osteophytic formations ${ }^{(2,6,9)}$. In radiological examination, opacity increase and capsular tension due to increased purulence or increased purulence with gas were detected in 18 cases, and intraarticular narrowing and degeneration on the joint surface were detected in 6 cases, while in 26 cases, there was no abnormality in bone tissue and joint detected.

In arthritis cases, early diagnosis is very difficult before clinical symptoms occur; however, it is possible to diagnose arthritis without clinical symptoms by diagnostic ultrasonography ${ }^{(9)}$. It is reported that a number of changes in synovial fluid volume, echogenic appearance of synovial fluid, synovial membrane, joint surface, and relation of joint with peripheral tissue will be formed with ultrasonographic examination ${ }^{(6,22)}$. In this study ultrasonographic examination of the cases with septic arthritis revealed that the synovial fluid had a hyperechogenic appearance and heterogeneous structure, and that there were corpuscular reflective bodies showing intense 
hyperechogenicity in the synovial fluid in 18 cases, while the articular cartilage surface clearly formed a hyperechoic line and had a smooth surface in 6 cases. In 26 cases with arthritis, no abnormality was detected.

The synovial fluid is a plasma in normally clear or slightly pale yellow color with an egg white appearance, with low fluidity and it contains proteins ${ }^{(7,9)}$. It is reported that synovial fluid in arthritis cases is blurry in colors ranging from light yellow to dark yellow-brown, has a decreased viscosity and increased volume, and that joint fluid contains fibrin clots and is purulent in most cases ${ }^{(11,19)}$. In this study, the synovial fluid of 7 cases showed mobile, clear and normal appearance, the synovial fluid of 25 cases had decreased viscosity, and was observed in colors varying between light yellow and dark yellow-brown, and synovial fluid was purulent in 18 cases.

It is reported that $M$. bovis is the most common microorganism isolated from synovial fluid in cases of septic arthritis ${ }^{(6,7,13)}$. Others ${ }^{(7,22)}$ have indicated that $S$. aureus is the most commonly isolated microorganism in cases of septic arthritis. Mulon et $a l^{(17)}$ have stated that the most common microorganism was Trueperella pyogenes in 172 cases with septic arthritis and Dogan et al $l^{(18)}$ have stated that the most common microorganisms isolated were Trueperella pyogenes and E. coli in 82 calves with septic arthritis. In this study, S. aureus was the most common $(\mathrm{n}=13)$. The other microorganisms identified were Streptococcus pluranimalium $(\mathrm{n}=8)$, Trueperella pyogenes $(\mathrm{n}=$ 8), M. bovis $(\mathrm{n}=6)$, E. coli $(\mathrm{n}=5)$ Saprophyte $\mathrm{spp} .(\mathrm{n}=1)$ and Acinetobacter $\mathrm{spp} .(\mathrm{n}=1)$ according to isolation prevalence.

As a result, it was concluded that clinical, radiological, utrasonographic examinations and physical and microbiological examinations of synovial fluid provide detailed information during the diagnosis of septic arthritis in calves, and that findings of microbiological examination provide important information especially in the early diagnosis of the disease, and contribute to the treatment in a large extent. It is suggested to comment that in the present study the agent that was isolated with more frequency was $S$. aureus $(\mathrm{n}=13)$.

The authors declare that they have no financial or personal relationships that may have inappropriately influenced them in writing this article. 


\section{Literature cited:}

1. Nouri M, Marjanmehr SH, Nowrouzian I. Deep septic arthritis of the fetlock joint in two dairy cows: clinical, radiographic and pathomorphologic findings. J Anim Poult Sci 2013;2(1):19-26.

2. Temizsoylu MD, Yigitarslan K. Arthritis and treatment options in bovine foot diseases. Türkiye Klinikleri J Vet Sci Surg-Special Topics 2015;1(1):66-72.

3. Kamiloglu A. Çiftlik hayvanlarında ayak hastalıkları. 1. Baskı, Medipres, Ankara, Türkiye: 2014.

4. Francoz D, Desrochers A, Latouche SJ. Effect of repeated arthrocentesis and single joint lavage on cytologic evaluation of synovial fluid in 5 young calves. Can J Vet Res 2007;71:129-134.

5. Heppelmann M, Kofler J, Meyer H, Rehage J, Starke A. Advances in surgical treatment of septic arthritis of the distal interphalangeal joint in cattle: A review. The Vet J 2009;182:162-175.

6. Desrochers A, Francoz D. Clinical management of septic arthritis in cattle. Vet Clin Food Anim 2014;30:177-203.

7. Goodarzi M, Khamesipour F, Mahallati SA, Karimi M, Azizi D, Azizi S. Study on prevalence of bacterial causes in calves arthritıs. ARPN J Agr Bio Sci 2015;10:6.

8. Jesse FFA, Bitrus AA, Abba Y, Mahadzar M, Hambalı IU, Peter ID, Haron AW, Lila MAM, Saharee AZ. Clinical management of septic arthritis in a sheep: A case report. Adv Anim Vet Sci 2017;5(6):267-270.

9. Gokhan N, Ozturk S. Evaluation of clinic, radiographic, ultrasonographic and histopathological findings of arthritis cases in calves. Erciyes Üniversitesi Vet Fak Derg 2016;13(1):19-29.

10. Yurdakul G, Saritas ZK. Evaluation of clinic, radiographic and some biochemical blood serum and synovial fluid parameters of arthritis cases in calves. Kocatepe Vet J 2013;6(2):13-22.

11. Nuss K. Synovial structures - cure or no cure? In. SIVAR International Congress, Cremona, Italy. 2011:39-40.

12. Arican M. Sığır cerrahi atlası. 1. Bask1. 290-96, Damla ofset A.Ş. Konya, Türkiye. 2017.

13. Shoieb SM, Sayed M, Ahmed M. Clinical and clinicopathological findings of arthritic camel calf associated with mycoplasma infection (Camelus dromedarius). J Dairy Vet Anim Res 2016;3(1):68. 
14. Landerer MCH, Habermacher J, Wenger B, Suter MM, Steiner A. Slow release antibiotics for treatment of septic arthritis in large animals. The Vet J 2010;184:14-20.

15. Rohde C, Anderson DE, Desrochers A, St-Jean G, Hull BL, Rings DM. Synovial fluid analysis in cattle: A review of 130 cases. Vet Surg 2000;29:341-346.

16. Jackson P. Treatment of septic artritis in calves. Farm Anim Pract 1999;596-601.

17. Mulon PY, Desrochers A, Francoz D. Surgical management of septic arthritis. Vet Clin Food Anim 2016;32:777-795.

18. Dogan E, Yanmaz LE, Okumus Z, Kaya M, Senocak MG, Cengiz S. Radiographic, ultrasonographic and thermographic findings in neonatal calves with septic arthritis: 82 cases (2006-2013). Atatürk Üniversitesi Vet Bil Derg 2016;11(1):6-12.

19. Gharagozlou MJ, Najafi J, Tabatabayi AH, Khazrainia P. Apathologic and microbiologic study on bovine arthritis associated with mycoplasma spp. Arch Razi Ins 2004;58:97-104.

20. Arican M, Elma E, Ozkan K. Clinical evaluation of infectious arthritis in extremities in calves. Turkish J Vet Surg 1998;4(1-2):5-7.

21. Bumin A, Temizsoylu MD, Kibar M, Alkan Z. Clinical, radiographic and arthroscopic evaluation of prulent arthritis in calves. Ankara Üniv Vet Fak Derg 2001;48:183-187.

22. Gorgul OS, Salci H, Özakin C, Cilo BD, Seyrek-Intas D, Celimli N, Cecen G. Arthroscopic diagnosis and comparison of arthroscopic lavage and intraarticular antibiotic applications in the treatment of experimentally induced different stage septic arthritis in goats. Kafkas Univ Vet Fak Derg 2010;16(6):957-967. 